p-ISSN: 2088-6991

e-ISSN: $2548-8376$

Juni 2019
Jurnal Tarbiyah: Jurnal Ilmiah Kependidikan

Vol. 8 No. 1. Januari - Juni 2019 (1-12)

\title{
RE-KONSIENTISASI DALAM DUNIA PENDIDIKAN
}

\section{(Membangun Kesadaran Kritis Melalui Pemikiran Paulo Freire)}

\author{
Rohinah \\ Fakultas Ilmu Tarbiyah dan Keguruan UIN Sunan Kalijaga Yogyakarta \\ Email: rohinah80@yahoo.com \\ Received: Desember 2018; Accepted: Juni 2019; Published: Juni 2019
}

\begin{abstract}
Educational idealism for humanizing humans must be in line with the goals and praxis of education. This is due to the fact that there are still many practices in educational institutions that still provide dominance on cognitive aspects and memorization aspects in understanding even the practice of learning and even religious learning. Therefore, the presence of critical thinkers such as Paulo Freire, is an effort to fight for education towards a real change so that education is not just preparing future mechanical robots but is able to give birth to human beings carrying change towards a just and civil society.
\end{abstract}

Keywords: Concientitation; Education; Critical Awareness

\section{ABSTRAK}

Idealisme pendidikan untuk memanusiakan manusia harus sejalan dengan tujuan dan praksis pendidikan. Masih banyaknya praktek di lembaga-lembaga pendidikan yang masih memberikan dominasi pada aspek kognitif dan aspek hafalan dalam memahami praktek pembelajaran bahkan pembelajaran agama sekalipun. Hadirnya pemikir kritis sebagaimana Paulo Freire, merupakan upaya memperjuangkan pendidikan menuju sebuah perubahan nyata agar pendidikan tidak hanya sekedar mempersiapkan robotrobot mekanik masa depan melainkan mampu melahirkan manusia-manusia pembawa perubahan menuju masyarakat yang berkeadilan dan berkeadaban.

Kata Kunci: Konsientisasi; Pendidikan; Kesadaran Kritis

\section{PENDAHULUAN}

Pendidikan

adalah

proses

memanusiakan manusia. Sebuah cita-cita yang sangat ideal dan mulia. Namun kenyataannya idealisme yang dicita-citakan untuk meningkatkan derajat kemanusiaan melalui dunia pendidikan tidak selamanya sejalan dengan apa yang diharapkan. Hal ini dapat disaksikan dari realitas yang ada di sekitar kita bahwa pendidikan masih memainkan peran tradisionalnya dengan memandang bahwa peserta didik merupakan produk yang dihasilkan oleh dunia pendidikan.

Padahal dalam dunia pendidikan sendiri sepertinya belum memainkan peran strategisnya dalam menciptakan pribadipribadi peserta didik yang unggul dan berkepribadian baik. Hal ini disebabkan masih banyaknya praktek di lembagalembaga pendidikan yang masih memberikan dominasi pada aspek kognitif dan penekanan pada aspek hafalan dalam memahami praktek pembelajaran bahkan pemabelajaran agama sekalipun. Capaian keberhasilan seorang anak hanya berhenti pada nilai angka-angka nominal semata, kepintaran anak dinilai manakala mampu menghafal materi-materi yang sudah ditentukan berdasarkan bahan ajar yang ada dan batasan-batasan yang sudah dipersiapkan secara terukur dan terstruktur menurut aturan yang sangat sempit dan sangat minim terhadap ruang dialoginteraktif antar guru dan peserta didik. Anak hanya terjebak pada batasan salah dan benar, baik dan buruk, surga dan neraka, serta pahala dan siksa. Sehingga sangat sempit ruang bagi anak untuk bisa berpikir kreatif dan kritis, karena jawaban-jawaban anak didik ditentukan oleh benar dan salah yang ditentukan dalam buku-buku teks ajar semata. 
Dalam hal ini kritik Munir Mulkhan terhadap dunia pendidikan sangat nyata dengan menegaskan bahwa persoalan moral yang sedang dialami bangsa ini dimulai dari ruang kelas yang cacat moral dan memasung daya kritis dan kreativitas. Anak-anak hanya dipandang sebagai sosok yang hanya berharga jika sesuai citra guru, pengelola pendidikan, dan pemerintah. Anak-anak tidak pernah diajak untuk mengerti, mengalami, dan menyadari kebaikan dan kebenaran saat semuanya tersedia oleh paket-paket pembelajaran. Tuhan pun tak pernah dikenal dan disadari, kecuali sifatsifat hebat Nya yang harus dihafal tanpa bertanya. Penindasan kehendak adalah pengalaman paling jelas dan otentik sejak anak-anak manusia memasuki bangku sekolah (Abdul Munir Mulkhan, 2002: 74-75).

Berangkat dari kegelisahan tersebut, maka hadirnya para pemikir kritis sebagaimana Paulo Freire, Ivan Illich, Erich Fromm dan sebagainya yang gigih memperjuangkan pendidikan menuju sebuah perubahan nyata adalah bukti konkrit bahwa dunia pendidikan yang selama ini dianggap sakral dan sarat dengan nilai-nilai kemanusiaan perlu dikaji ulang. Agar pendidikan tidak hanya sekedar mempersiapkan robot-robot mekanik masa depan melainkan mampu melahirkan manusia-manusia pembawa perubahan menuju masyarakat yang berkeadilan dan berkeadaban.

\section{A. Sekilas Tentang Paulo Freire}

Paulo Freire dilahirkan di Recife, sebuah kota pelabuhan bagian selatan Brasil pada 19 September 1921. Recife merupakan sebuah kota yang terbelakang dan miskin. Freire dikenal sebagai tokoh pendidikan yang dianggap kritis dan kontroversial. Ia menggugat sistem pendidikan yang telah mapan dalam masyarakat Brasil.

Ayahnya bernama Joaquim Temistocles Freire, berprofesi sebagai polisi militer di Pernambuco yang berasal dari Rio Grande de Norte. Ibunya, Edeltrus Neves Freire, berasal dari Pernambuco. Merekalah yang dengan contoh dan cinta mengajarkan kepada Paulo Freire untuk menghargai dialog dan menghormati pendapat orang lain (http://mariatulkiftiah.blogspot.comn/2011/06/paulo -Freire-dan-pemikirannya.html).

Pada tahun 1929 krisis ekonomi melanda Brasil. Orang tuanya, yang termasuk kelas menengah terkena imbas krisis itu dan mengalami kejatuhan financial yang sangat hebat. Akibat kondisi seperti itu, Freire terpaksa belajar mengerti apa artinya menjadi lapar bagi seorang anak sekolah. Sehingga pada umur 11 tahun, karena pengalaman yang mendalam akan kelaparan, bertekad untuk mengabdikan kehidupannya pada perjuangan melawan kelaparan, agar anak-anak lain jangan sampai mengalami kesengsaraan yang tengah dialaminya (Sumaryo, 1981: 29).

Pada tahun 1943, Freire mulai belajar di Universitas Recife, sebagai seorang mahasiswa hukum, tetapi ia juga belajar filsafat dan psikologi bahasa. Meskipun ia lulus sebagai ahli hukum, ia tidak pernah benar-benar berpraktik dalam bidang tersebut. Sebagai buktinya, ia pernah berkarier dalam waktu pendek sebagai seorang pengacara. Sebaliknya, ia bekerja sebagai seorang guru di sekolah-sekolah menengah, mengajar bahasa Portugis selama 6 tahun (1941-1947).

Sekitar tahun 1944, ia menikah dengan seorang guru bernama Elza Maia Costa Olievera, seorang rekan gurunya. Pernikahan inilah yang memantapkan pergeseran interesnya dari bidang hukum ke bidang pendidikan, sebagaimana diakuinya sendiri, ". . . precisely after my marriage when I started to have a systematic interest in educational problems." Mereka berdua bekerja bersama selama hidupnya sementara istrinya juga membesarkan kelima anak mereka. 
Pada 1946, Freire diangkat menjadi Direktur Departemen Pendidikan dan Kebudayaan dari Dinas Sosial di Negara bagian Pernambuco (yang ibu kotanya adalah Recife). Selama bekerja itu, terutama ketika bekerja di antara orang-orang miskin yang buta huruf, Freire mulai merangkul bentuk pengajaran yang non-ortodoks yang belakangan dianggap sebagai teologi pembebasan.

Tahun 1959, Freire menyerahkan disertasi doktoral di Universitas Recife dengan judul Educacao e Atualidade Brasileira (Pendidikan dan Keadaan Masa Kini di Brasil). Di kemudian hari, ia bahkan diangkat sebagai guru besar bidang sejarah dan filsafat pendidikan di universitas tersebut.

Pada 1961-1964, ia diangkat sebagai Direktur Pertama dari Departemen Perluasan Kebudaya Universitas Recife. Dan pada 1962, ia mendapatkan kesempatan pertama untuk menerapkan secara luas teori-teorinya. Saat itu, 300 orang buruh kebun tebu diajar untuk membaca dan menulis hanya dalam 45 hari. Sebagai tanggapan terhadap eksperimen ini, pemerintah Brasil menyetujui dibentuknya ribuan lingkaran budaya di seluruh negeri.

Karena keberhasilannya dalam program pemberantasan buta huruf di daerah Angicos, Rio Grande do Norte, ia diangkat sebagai Presiden dari Komisi Nasional untuk Kebudayaan Populer. Pada tahun 1964, terjadi kudeta militer di Brasil, yang mengakhiri upaya itu (Paulo Freire, 1972: xii). Rezim yang berkuasa saat itu menganggap Freire seorang tokoh yang berbahaya, karena itu mereka menahannya selama 70 hari sebelum akhirnya "mempersilahkan" Freire untuk meninggalkan negeri itu. Ia memulai masa 15 tahun pembuangannya dan tinggal untuk sementara waktu di Bolivia. Dari Bolivia ia pindah ke Chili dan berkerja selama 5 tahun untuk organisasi internasional Christian
Democratic Agrarian Reform Movement. Dalam masa 5 tahun ini, ia dianggap sangat berjasa menghantar Chili menjadi 1 dari 5 negara terbaik di dunia yang diakui UNESCO sukses dalam memberantas buta huruf. Pada tahun 1969, ia sempat menjadi visiting professor di Universitas Harvard.

Antara tahun 1969-1979, ia pindah ke Jenewa dan menjadi penasihat khusus bidang pendidikan bagi Dewan Gereja Dunia. Pada masa itu Freire bertindak sebagai penasihat untuk pembaruan pendidikan di bekas koloni-koloni Portugis di Afrika, khususnya Guinea Bissau dan Mozambik. Pada akhir tahun 1960-an inilah ia menulis salah satu bukunya yang paling terkenal, Pedagogy of the Oppressed.

Pada tahun 1979, Freire kembali ke Brasil dan menempati posisi penting di Universitas Sao Paulo. Freire bergabung dengan Partai Buruh Brasil di kota São Paulo, dan bertindak sebagai penyedia untuk proyek melek huruf dewasa dari tahun 19801986. Ketika PT menang dalam pemilupemilu munisipal pada 1986, Freire diangkat menjadi Sekretaris Pendidikan untuk São Paulo.

Pada tahun 1986 juga, istrinya Elza meninggal dunia. Kemudian Freire menikahi Maria Araújo Freire dan melanjutkan pekerjaan pendidikannya sendiri yang radikal. Tahun 1988, ia ditunjuk menjadi Menteri Pendidikan untuk kota Sao Paulo, sebuah posisi yang memberinya tanggung jawab untuk mereformasi dua pertiga dari seluruh sekolah negeri yang ada.

Pada 1991, didirikanlah Institut Paulo Freire di São Paulo untuk memperluas dan menguraikan teori-teorinya tentang pendidikan rakyat. Institut ini menyimpan semua arsip Freire. Freire meninggal pada 2 Mei 1997, dalam usia 75, akibat penyakit jantung. Selama hidupnya, ia menerima beberapa gelar doktor honoris causa dari berbagai universitas di seluruh dunia. Ia juga 
menerima beberapa penghargaan, di antaranya:

1. UNESCO's Peace Prize tahun 1987.

2. Dari The Association of Christian Educators of the United States sebagai The Outstanding Christian Educator pada tahun 1985.

3. Penghargaan Raja Baudouin (Belgia) untuk Pembangunan Internasional

Beberapa karya Paulo Freire yaitu:

Education As The Practice of

Freedom. Buku ini dibuat Freire atas hasil analisisnya terhadap kegagalan dalam melakukan emansipasi di Brazil, buku ini ditulis didalam penjara sebab aktivitas subversive Freire ia tertangkap oleh militer yang berhasil meruntuhkan rezim goulart, dan memerintahkan untuk mengintimidasi seluruh geraka prograsif, termasuk salah satunya adalah gerakan pemberantasan buta huruf Freire, maka Freire pun dipenjara selama 70 hari. Buku ini kemudian diselesaikan di Cile dalam masa pembuangannya. Bbuku ini menjelaskan tentang apa pandangan filosofis dari apa yang terwujud dari masyarakat untuk mentransformasi sejarah menjadi subjek melalui suatu refleksi yang kritis.

Pedagogy of the Opressed (1970), salah satu karya Freire yang terkenal, dibuatnya ketika Freire mulai menagkap realita kongkret yang terjadi atas kenyataan perang yang dilancarkan Amerika terhadap Vietnam, dimana tekanan dan penindasan terhadap kehidupan ekonomi dan politik dunia ketiga berlangsung secara tak terbatas. Berdasarkan kenyataan tersebut Freire mulai memperluas definisinya tentang persoalan dunia ketiga dari masalah geografis ke konsep politis, dalam buku ini tema kekerasan menjadi pokok bahasan utama, menurut Freire pendidikan menjadi jalur permanen terwujudnya pembebasan. Dalam buku ini Freire berusaha menyajikan pandangan filosofis dari apa yang terwujud dari para laki-laki dan perempuan untuk mentransformasi sejarah dan menjadi subjek melalui satu refleksi yang kritis.

Cultural Action for Freedom (1970), buku yang ditulis Freire pada tahun yang sama pembuatan karya Pedagogy of the Oppressed. Dalam buku ini Freire membahas masalah perubahan-perubahan kultural yang terjadi dalam reformasi agraria berjalan seiring dengan pengajaran dan pembelajaran ketrampilan baru. Tahun 1969-1970

Freire menerbitkan dua buah artikel untuk Harvard Educational Review yang berjudul "Adult Literacy Process as Cultural Action for Freedom" dan "Cultural Action an Conscientization". Kedua artikel ini memuat hamper seluruh teori kependidikannya kedalam bahasa Inggris yang pertama karena karya-karya tulisnya yang lain selalu dalam bahasa Spanyol dan Portugis. Pedagogy of the Heart (1999) merupakan buku paling menarik karena Freire berusaha melihat kedalam hidupnya sendiri untuk berefleksi tentang pendidikan dan politik. Freire menampilkan dirinya sebagai democrat yang tidak engenal kompromi dan pembaharu radikal yang gigih, pengalamannya semasa dalam pembuangan hingga pengalamannya dalam menjabat sebagai mentri pendidikan Sao Paolo justru semakin memperbesar komitmennya kepada orang-orang terpinggir, lapar dan buta huruf akibat rezim Brazil yang menindas.

\section{B. Pendidikan "Gaya Bank" Sebagai Bentuk Penindasan}

Filsafat Freire bertolak dari kehidupan nyata, bahwa di dunia ini sebagian besar manusia menderita sedemikian rupa, sementara sebagian lainnya menikmati jerih payah orang lain dengan cara-cara yang tidak adil, dan kelompok yang menikmati ini justru bagian minoritas umat manusia. Dilihat dari segi jumlah saja menunjukkan bahwa keadaan 
tersebut memperlihatkan kondisi yang tidak berimbang, tidak adil. Persoalan itu yang disebut Freire sebagai "situasi penindasan". (http://edukasi.kompasiana.com/2012/02/23/pau lo-freire-pendidikan-untuk-pembebasan437729.html).

Freire yang melatarbelakangi gagasan pembebasannya dari dimensi sosial politik yang menurutnya tirani pada waktu itu, ternyata merambah juga dalam dunia pendidikan. Menurutnya penindasan yang harus dilawan kesadaran kritis bukan hanya terjadi pada system dan struktur kekuasaan maupun sosial, melainkan penindasan sesungguhnya juga terjadi pada dunia pendidikan, yang disebut dengan pendidikan "gaya bank". Dalam pendidikan gaya bank di antaranya mencerminkan ;

1. Guru mengajar, murid diajar

2. Guru mengetahui segala sesuatu, murid tidak tahu

3. Guru berpikir, murid dipikirkan

4. Guru bercerita, murid patuh mendengarkan

5. Guru menentukan peraturan, murid diatur

6. Guru memilih dan memaksakan pilihannya, murid menyetujui

7. Guru berbuat, murid membayangkan dirinya berbuat melalui perbuatan gurunya

8. Guru memilih bahan daan isi pelajaran, murid (tanpa diminta pendapatnya menyesuaikan diri dengan pelajaran itu

9. Guru mencampuradukkan kewenangan ilmu pengetahuan dan kewenangaan jabatannya, yang ia lakukan untuk menghalangi kebebasan murid

10. Guru adalah subjek dalam proses belajar, murid adalah objek (Mujamil Qomar, 2012: 134).

Pendidikan gaya bank inilah yang menurut Freire menjadi penyebab lahirnya budaya bisu, dan dari budaya bisu inilah sesungguhnya tengah terjadi proses penindasan. Dan proses penindasan itu dimulai dari hierarki atas-bawah yakni yang menindas, antara pemegang kekuasaan dengan rakyat jelata, antara superior dengan inferior, antara guru dengan murid, sebagaimana pernyataan Freire berikut ini: "Kekerasan disulut oleh para penindas, yang mengeksploitasi, yang tak mengakui orang lain sebagai manusia-bukan disulut oleh yang ditindas yang dieksploitasi, yang tak diakui. Bukan orang yang tak dicintai yang memulai ketiadaan cinta, melainkan karena orang yang tak bisa mencinta karena yang dicintainya hanya dirinya sendiri." (Omi Intan Naomi, 2009; 445).

Pendidikan gaya bank inilah yang disebut-sebut Freire menjadi faktor penyebab terjadinya proses penindasan dalam dunia pendidikan, karena anak didik hanya dianggap sebagai objek sementara guruadalah subjek. Konsep pendidikan gaya bank menyamakan manusia sebagai makhluk yang dapat disamakan dengan benda yang gampang diatur. Freire menyebutkan :

"Semakin banyak tabungan yang dititipkan kepada mereka semakin kurang mengembangkan kesadaran kritis yang dapat mereka peroleh dari keterlibatan dunia sebagai pengubah dunia tersebut". (Paulo Freire, 2008:54)

Oleh karena itu, Paulo freire mengkritik model pendidikan gaya bank tersebut, dimana murid dianggap sebagai pengumpul ilmu pengetahuan dari gurunya, dan suatu saat nanti ilmu pengetahuan yang dikumpulkannya tersebut dikeluarkan dalam bentuk yang sama persis apa yang telah guru transfer kepada mereka. Menurutnya, pendidikan gaya bank ini merupakan warisan kolonial, dimana pendidikan dibuat demi memenuhi kepentingan kaum penguasa. Hasilnya, akan menghasilkan peserta didik yang juga mewarisi dan bergerak sesuai dengan kepentingan kaum penguasa, menindas bahkan kepada sesamanya. Dari sinilah maka, pendidikan gaya bank ini dikritik sebagai bentuk dehumanisasi. 


\section{Konsep Pendidikan Pembebasan Paulo Freire}

\section{Humanisasi}

Humanisasi menurut Freire adalah sebuah keniscayaan dan harus diperjuangkan, karena itulah sesungguhnya hakikat dan fitrah manusia. Kalaupun selama ini telah terjadi proses dehumanisasi ( keadaan kurang dari manusia atau tidak lagi manusia) itulah fakta sejarah, melainkan bukan fitrah sejarah. Dalam hal ini Freire menegaskan: "perjuangan untuk meraih pemanusiaan, perjuangan demi emansipasi tenaga kerja, demi menaklukkan keterasingan, demi peneguhan manusia sebagai pribadi, akan kehilangan makna bila dehumanisasi diakui sebagai fitrah sejarah. Perjuangan menjadi mungkin karena dehumanisasi meski merupakan fakta sejarah - bukan takdir manusia melainkan produk tatanan yang tidak adil yang melahirkan kekerasan para penindas, yang pada gilirannya mengubah kaum tertindas menjadi kurang dari manusia". (Paulo Freire, 2008: 435).

Maka dari itu, ikhtiar memanusiakan kembali manusia (humanisasi) merupakan pilihan mutlak. Humanisasi satu-satunya pilihan bagi kemanusiaan, karena walaupun dehumanisasi adalah kenyataan yang terjadi sepanjang sejarah peradaban manusia dan tetap merupakan suatu kemungkinan ontologis di masa mendatang, ia bukanlah suatu keharusan sejarah. Secara dialektis, suatu kenyataan tidak mesti menjadi suatu keharusan. Jika kenyataan menyimpang dari keharusan, maka menjadi tugas manusia untuk merubahnya agar sesuai dengan apa yang seharusnya (the man's ontological vocation).

(http://edukasi.kompasiana.com/2012/02/23/ paulo-freire-pendidikan-untuk-pembebasan437729.html.)
Menurut Freire pendidikan yang humanis adalah; pertama pendidikan yang mempertegas dan memperjelas arah pendidikan yang membebaskan dan memerdekakan, yaitu sebuah upaya pemberdayaan masyarakat tertindas menuju sebuah paradigma kritis dan trasformatif dalam mewujudkan sebuah kebebasan sebagai hak asasi setiap manusia.

Kedua, pendidikan yang selalu menjadi pendamping dan pengawal segala dinamika kehidupan. Dari definisi ini kemudian Freire menfokuskan kajiannya pada sebuah keadaan dalam kebudayaan, pengetahuan dan kondisi suatu kelompok masyarakat.

Ketiga, pendidikan emansipatoris yaitu pendidikan yang tidak saja menjalankan peranannya sebagai proses pengalihan pengetahuan. Atau hanya sekedar proses pengumpulan data dan informasi yang disebutkannya penyimpanan (banking), melainkan mengetahui harus menjadikan peserta didik sebagai makhluk yang "menjadi" subjek dan hidup secara aktif merasakan persoalan dan ikut terlibat dalam lika-liku kehidupan. Itu berarti mengetahui juga harus melakukan analisis dan kritis terhadap konstruksi masyarakat yang sedang terbentuk maupun dibentuk oleh lingkungan (Moh.Yamin, 2009: 145).

Oleh karena itu, proses menuju humanisasi Freire adalah menjadikan manusia pencipta (the creator) sejarahnya sendiri. Karena seseorang hidup di dunia dengan orang-orang lain sebagai umat manusia, maka kenyataan "ada bersama" (being together) itu harus dijalani dalam proses menjadi (becoming) yang tak pernah selesai. Ini bukan sekedar adaptasi, namun integrasi untuk menjadi manusia seutuhutuhnya.

\section{Pendidikan Hadap-Masalah (problem-posing education)}

Paulo Freire memiliki pandangan yang lebih menekankan peserta didik 
sebagai subjek yang bebas ketimbang objek yang hanya menerima pengetahuan dari manusia yang dianggap lebih tahu kepada manusia yang dianggap belum tahu. Pendidikan kontekstual atau hadap masalah adalah sebuah teori dan model pendidikan yang mengupayakan peserta didik untuk menjadi subyek dalam rangka menjawab persoalan-persoalan yang muncul dalam realitas sosial. Freire menekankan peran berpikir dalam pembuatan kembali dunia. Dari sini fakta sosial bisa diungkapkan melalui pendidikan, dan menurut Freire, harus diupayakan adanya penyatuan (integration) dunia fakta (nyata) ke dalam dunia pendidikan (Moh. Yamin, 2009: 19).

Freire memiliki anggapan dasar bahwa fitrah manusia secara ontologis adalah menjadi subyek yang bertindak terhadap dan mengubah dunianya. Dunia ini sebagaimana yang dikatakannya bukanlah suatu tatanan yang statis dan tertutup, suatu realitas yang telah pasti (given) di mana seseorang harus menerima dan menyesuaikan diri, melainkan dunia ini adalah suatu masalah yang harus digeluti dan dipecahkan. Dunia adalah bahan mentah yang digunakan manusia untuk menciptakan sejarah, suatu tugas yang dijalankannya ketika ia memerangi apa saja yang tidak manusiawi kapan saja dan dimana saja, serta berani menciptakan kualitas baru (Paulo Freire, 2008: xii).

Pendidikan bagi Paulo Freire, adalah pendidikan yang mendekatkan manusia kepada kemanusiaannya. Dimana soal rasa sebagai manusia termanifestasi didalam pendidikan gaya hadap masalah. Bukan pendidikan yang menjauhkan peserta didik dari kemanusiaannya, memisahkan peserta didik dari realitas yang dihadapinya sebagai manusia, yang memiliki pengalaman, rasa, aspirasi, suara, bahasa, untuk dipahami, didengarkan, dan saling mendengarkan.

Dengan demikian, setiap anak didik secara langsung dilibatkan dalam permasalahan-permasalahan realitas dunia dan keberadaan diri mereka di dalamnya. Karena itu, Freire juga menyebut model pendidikannya sebagai "pendidikan hadap masalah" (problem posing education). Anak didik menjadi subyek yang belajar, subyek yang bertindak dan berpikir, dan pada saat bersamaan berbicara menyatakan hasil tindakan dan buah pikirannya. Dan begitu juga sang guru.

\section{Dialog : Hakekat Pendidikan Sebagai Bentuk Kebebasan}

Menurut Freire dialog antar manusia harus bedasarkan atas kepekaan terhadap kemampuan bawaan untuk menemukan diri sendiri. Dialog mengandaikan kerendahan hati, yaitu kemauan belajar dari orang lain meskipun menurut perasaan kebudayaan dianggap lebih rendah; memperlakukan orang lain sederajat; keyakinan bahwa orang lain dapat mengajar kita. Dialog menuntut keparcayaan yang besar bahwa manusia pada hakikatnya dipanggil untuk menjadi subjek yang harus mengubah dunia; membuat kehidupan ini semakin penuh dan semakin kaya, baik secara individual maupun secara kolektif. Dialog menuntut sikap mau mendengar dan memahami diri sendiri bahwa manusia sebagai makhluk yang belum selesai (Paulo Freire, 2008: xxiii).

\section{Konsientisasi Sebagai Perantara Pendidikan Manusiawi}

Kegiatan untuk menyadarkan peserta didik tentang realita ketertindasannya ini ia sebut sebagai konsientasi. Konsientisasi adalah pemahaman mengenai keadaan nyata yang sedang dialami peserta didik. Konsientisasi dalam bahasa Indonesia diartikan kesadaran. Secara etimologis kesadaran berarti 1) keinsafan, keadaan mengerti, 2) hal yang dirasakan atau dialami oleh seseorang, seperti kesadaran diri, keadaan seseorang atas keadaan dirinya sendiri. Sedangkan secara terminologis kesadaran dapat diartikan sebagai timbulnya 
sikap megetahui, memahami, menginsafi, dan menindaklanjuti sesuatu kegiatan untuk mencapai tujuan tertentu. Dalam rumusan Mujamil Qomar yang dimaksud kesadaran pendidikan merupakan kehadiran sikap mengetahui, memahami, menginsafi, dan menindaklanjuti proses pembimbingan untuk mengembangkan potensi kemampuan seseorang menjadi sumber daya manusia yang kuat (strong human resources) (Tim Penyusun Kamus Pusat Pembinaan dan Pengembangan Bahasa Departemen Pendidikan dan Kebudayaan, 1991: 859 dan Mujamil Qomar, 2012: 119-120).

Istilah penting yang diajukan Freire dalam Pedagogy of The Oppressed untuk mengajukan teorinya adalah penyadaran (conscientizacao) atau yang sering kita sebut "konsientisasi". Konsientisasi adalah pemahaman mengenai keadaan nyata yang sedang dialami siswa atau murid. Meskipun wilayah terakhir yang ingin dituju adalah perubahan sistemik, namun pendidikan Freire bertujuan untuk pembebasan dan pemanusiaan (humanisasi). Dalam rangka itulah Freire melihat bahwa 'penyadaran' (konsientisasi) sebagai inti dari pendidikannya. Pendidikan harus bertujuan menyadarkan peserta didik akan realitas sosialnya.

Freire (1979) membagi kesadaran manusia menjadi kesadaran magis, naif, dan kritis. Pertama, kesadaran magis (magical consciousness) adalah kesadaran mesyarakat yang tidak mampu melihat kaitan antara satu faktor dengan faktor lain. Misalnya masyarakat miskin yang tidak mampu melihat kaitan antara kemiskinan mereka dengan sistem politik dan kebudayaan. Kesadaran ini lebih melihat pada faktor di luar manusia (natural maupun supranatural) sebagai penyebab dari ketidakberdayaannya.

Kedua, kesadaran naif (naival consciousness) yang lebih melihat aspek manusia menjadi akar permasalahan dalam masyarakat. Dalam kesadaran ini, masalah etika, kreativitas, need for achievement dianggap sebagai penentu perubahan sosial. Jadi dalam menganalisis mengapa suatu masyarakat miskin, mereka menganggap hal itu karena salah mereka sendiri.

Ketiga, kesadaran kritis (critical cinsciousness) yang lebih melihat pada aspek sistem dan struktur sebagai sumber masalah. Pendidikan mencoba menganalisis secara kritis sistem dan struktur sosial, politik, ekonomi, budaya, dan konteks masyarakat lainnya. Paradigma kritis dalam pendidikan adalah melatih siswa agar mampu mengidentifikasi ketidakadilan dalam sistem dan struktur yang ada, kemudian menganalisis bagaimana sistem itu bekerja, serta bagaimana mentransformasikannya. Tugas pendidikan dalam paradigma ini adalah menciptakan ruang dan kesempatan agar siswa terlibat aktif dalam proses penciptaan struktur yang secara fundamental baru dan lebih baik (William A. Smith, : 2001, lihat jugaRoem Topatimasang, Toto Rahardjo, dan Mansour Fakih,2010: xvi)

Manusia berkesadaran magis pada umumnya hanya dapat "menyesuaikan" diri dengan lingkungan. sedang manusia berkesadaran "naif" hanya berusaha memperbaharui, tapi berbeda dengan keduanya, manusia berkesadaran kritis akan senantiasa berfikir bagaimana "mengubah" keadaan yang terjadi menuju keadaan yang lebih baik.

Dengan demikian, kesadaran pendidikan memiliki fungsi yang sangat penting dalam mewujudkan keberhasilan pendidikan. Fungsi tersebut dapat diidentifikasi sebagai berikut. Pertama, menyadari dan melaksanakan tanggungjawab pendidikan secara optimal. Kesadaran dan aksi tersebut tumbuh dari dalam dirinya sendiri sehingga merupakan kesadaran dan aksi yang alamiah (natural).

Kedua, menumbuhkan semangat belajar. Orang-orang yang sadar pendidikan 
selalu menempatkan pendidikan pada posisi yang penting dalam kehidupan dunia. Ketiga, mengoreksi kelemahan dan kekurangan diri sendiri (introspeksi). Orangorang yang memiliki kesadaran pendidikan sepenuhnya memiliki kecenderungan ke dalam lebih dahulu daripada keluar. Kecenderungan ke dalam dimaksudkan memperhatikan, menelusuri, menilai, dan mencermati kelemahan-kelemahan dan kekurangan-kekurangan dalam ranah pendidikan.

Keempat, mengarahkan dan mengendalikan perilaku. Kesadaran dapat memantau perilaku dan tindakan kita, lebih dari itu, bahkan mengarahkan dan mengendalikannya sehingga tidak mudah terjebak daalm kesesatan. Kelima, menumbuhkan semangat berprestasi. Keenam, menumbuhkan mutu pendidikan (Mujamil Qomar, 2012: 141-146).

\section{Implementasi Konsep Pendidikan Paulo Freire dalam Dunia Pendidikan}

1. Tujuan Pendidikan

Menurut Freire, tujuan utama dari pendidikan adalah membuka mata peserta didik guna menyadari realitas ketertindasannya untuk kemudian bertindak melakukan transformasi sosial. Tujuan pendidikan harus berorientasi pada bagaimana menjadikan manusia-manusia yang terdidik menemukan kebebasannya, menjadi manusia merdeka, dan mengentaskan dari ketertindasan. Dan tujuan pendidikan yang humanis tersebut akan terwujud jika pendidikan bertujuan untuk membangun kesadaran anak didik. Karena menurut Freire kesadaran sesungguhnya menjadi intisari dari aktifitas kerja. Bahkan Freire menegaskan bahwa tindakan dikatakan kerja bukan karena usaha fisik, melainkan karena kesadaran yang dimiliki subjek dalam berusaha, memprogramkan tindakan, menciptakan alat, dan kemudian menggunakannya untuk memediasi diri dengan objek tindakannya, merumuskan tujuan, dan mengantisipasi masa depan (Paulo Freire, 2002: 128).

2. Materi Ajar dan Metode Pengajaran

Dalam pandangan Freire semua realitas yang ada merupakan bahan dan media yang bisa digunakan untuk menemukan pengetahuan-pengetahuan melalui daya pikir dan kreatiftas manusia. Dengan kata lain pembelajaran tidak hanya terbatas pada apa yang sudah ada dalam teks bahan ajar yang sudah disiapkan dan didesain sedemikian rupa menurut cara pandang orang lain, tapi peserta didik diberi kebebasan untuk menggali, menemukan, dan merumuskan pengertian baru melalui pengetahuan dan pengalaman yang selama ini di dapatkan dari realitas yang dihadapi.

Begitu juga dalam menggunakan metode pembelajaran haruslah mengarah pada upaya untuk mengembangkan daya nalar dan kreativitas peserta didik sesuai dengan kemampuan dan pengalaman yang sudah didapatkan. Sehingga peserta didik benar-benar diposisikan sebagai manusia merdeka yang memiliki kebebasan untuk berpikir, berkreasi dan berkarya.

Pendidikan harus memberi keleluasaan bagi setiap orang untuk mengatakan kata-katanya sendiri, bukan kata-kata orang lain. Murid harus diberi kesempatan untuk mengatakan dengan katakatanya sendiri, bukan kata-kata sang guru. Atas dasar itulah, Freire menyatakan bahwa proses pengaksaraan dan keterbacaan (alfabetisasi dan literasi) pada tingkat yang paling awal sekali dari semua proses pendidikan haruslah benar-benar merupakan suatu proses yang fungsional, bukan sekedar suatu kegiatan teknis mengajarkan hurufhuruf dan angka-angka serta merangkaikan menjadi kata-kata dalam kalimat-kalimat yang telah tersusun secara mekanis. Berdasarkan pengalaman dan dialognya dengan kaum petani miskin dan buta huruf (terutama di Brasil dan Chile), Freire 
kemudian menyusun suatu konsep pendidikan melek huruf fungsional menggunakan perbendaharaan kata-kata yang digali dari berbagai "tema pokok" (generative theme) pembicaraan sehari-hari masyarakat petani itu sendiri. Dalam pelaksanaannya, konsep pendidikan melek huruf fungsional Freire ini terdiri dari tiga tahapan utama:

1. Tahap Kodifikasi dan Dekodifikasi: merupakan tahap pendidikan melek huruf elementer dalam "konteks konkret" dan "konteks teoritis" (melalui gambargambar, cerita rakyat, dan sebagainya).

2. Tahap Diskusi Kultural: merupakan tahap lanjutan dalam satuan kelompokkelompok kerja kecil yang sifatnya problematis dengan menggunakan "katakata kunci" (generative words).

3. Tahap Aksi Kultural: merupakan tahap "praxis" yang sesungguhnya di mana setiap orang atau kelompok menjadi bagian langsung dari realitas (http://edukasi.kompasiana.com/2012/02/ 23/paulo-freire-pendidikan-untukpembebasan-437729.html).

Oleh karena itu, untuk membangun kesadaran peserta didik sebagai manusia yang merdeka dan memiliki kebebasan, metode pembelajaran tidak bisa dilakukan secara searah, harus dilakukan secara dua arah, di mana guru dan murid harus berada dalam kondisi sejajar agar murid tidak berperan sebagai obyek yang hanya berperan sebagai wadah yang harus diisi oleh ilmu pengetahuan yang hanya berasal dari sang guru (pendidikan gaya bank). Karena sesungguhnya dalam menghadapi permasalahan sehari-hari pengalaman setiap orang berbeda-beda dan berbeda pula cara mengatasi permasalahan yang dihadapi, sehingga tidak ada orang yang lebih pandai dari orang lain begitu juga sebaliknya.

\section{Guru Sebagai Fasilitator}

Hal positif yang dapat dipetik dari teori pendidikan kritis Freire mengenai penyadaran (konsientisasi) adalah bahwa pendidikan harus mendorong adanya proses dialogis antara guru (pengajar) dan anak didik. Maka dengan paradigma dialogis ini seorang pengajar harus rendah hati dan mengasihi peserta didiknya supaya terbuka terhadap berbagai kritik dari peserta didik. Sebaliknya, peserta didik seharusnya senantiasa kritis dan mempertanyakan kembali tentang hal yang belum diketahui oleh sang guru. Dari sini, akan terjadi komunikasi dua arah yang harmonis dan proses pembelajaran tidak hierarkis atasbawah, pintar-bodoh, sudah tahu-belum tahu dan seterusnya.

Oleh karena itu, pekerjaan atau kegiatan pendidik, kesadaran adalah menjadi nafasnya. Menurut Mujamil Qomar guru baru disebut pendidik apabila kegiatannya dilakukan dengan penuh kesadaran (Mujamil Qomar, 2012: 140).

\section{KESIMPULAN}

Membebaskan manusia dari kondisikondisi penindasan yang telah membawa kehidupan manusia pada sikap "tidak manusiawi" (dehumanisasi) merupakan tujuan utama dari agenda perubahan pendidikan ke arah pembebasan. Freire sangat mengkritik terhadap fenomena pendidikan gaya bank yang selama ini telah mapan, karena pendidikan tersebut menyebabkan terjadinya budaya bisu yang mencengkeram nilai-nilai kemanusiaan secara fitrah dan universal. Budaya bisu inilah awal mula dari sebuah penindasan. Maka pendidikan berfungsi untuk merubah itu semua.

Untuk mengentaskan dari segala situasi penindasan ini, terlebih dahulu manusia haruslah memiliki kesadaran bahwa telah terjadi penindasan dan memiliki perasaan bahwa ia mampu untuk merubah itu semua. 
Freire menggolongkan kesadaran manusia menjadi kesadaran magis (magical consciousness), kesadaran naïf (naival consciousness), dan kesadaran kritis (critical consciousness)

Kesadaran magis yakni suatu kesadaran masyarakat yang tidak mampu melihat kaitan antara satu faktor dengan faktor lainnya. Misalnya masyarakat miskin yang tidak mampu melihat kaitan antara kemiskinan mereka dengan sistem politik dan kebudayaan. Kesadaran magis lebih melihat faktor di luar manusia (natural maupun supranatural) sebagai penyebab dan ketidakberdayaan.

Kesadaran naïf, keadaan yang dikatagorikan dalam kesadaran ini adalah lebih melihat aspek manusia menjadi akar penyebab masalah masyarakat.

Kesadaran kritis, kesadaran ini lebih melihat aspek sistem dan struktur sebagai sumber masalah. Pendekatan struktural menghindari "blaming the victims" dan lebih menganalisis. Untuk secara kritis menyadari struktur dan sistem sosial, politik, ekonomi budaya dan akibatnya pada keadaan masyarakat.

Dan untuk mencapai pada upaya ke arah pendidikan yang membebaskan haruslah mengarah pada kesadaran kritis. Sehingga mengarahkan peserta didik untuk menemukan kesadaran kritis adalah sebuah keniscayaan jika pendidikan memiliki citacita untuk mewujudkan pendidikan yang humanis dan egalitarian.

\section{DAFTAR PUSTAKA}

Colins, Denis, Paulo Freire His Life, Works and Thought. (New York: Paulist Press, 1977)

Freire, Paulo, Pendidikan Kaum Tertindas. (Jakarta: LP3S, 1972)

Freire, Paulo, Pendidikan yang Membebaskan, Pendidikan yang Memanusiakan, dalam Naomi, Omi Intan, Menggugat Pendidikan: Fundamentalisme, Konservatif, Liberal, Anarkis, (Yogyakarta: Pustaka Pelajar, 2009)

Freire, Paulo, Politik Pendidikan, Kebudayaan, Kekuasaan dan Pembebasan, terj, Agung Prihantoro dan Fuad Arif Fudiyartanto, (Yogyakarta: READ (Research, Education and Dialogue) Bekerjasama dengan Pustaka Pelajar, 2002)

Http/ ELEMEN-ELEMEN KRITIS DALAM KONSEP PENDIDIKAN PAULO FREIRE.htm. di unduh pada tanggal 7 Maret 2015

http://edukasi.kompasiana.com/2012/ 02/23/paulo-freirependidikan-untukpembebasan-437729.html. diakses pada tanggal 7 Maret 2015

Kiftiah, Mariatul, Paulo Freire dan Pemikirannya, dalam http://mariatulkiftiah.blogspot. comn/2011/06/paulo-Freiredan-pemikirannya.html diakses pada 07 Maret 2015. 
Mulkhan, Abdul Munir, Nalar Spiritual Pendidikan, (Yogyakarta: PT. Tiara Wacana, 2002)

Qomar, Mujamil, Kesadaran Pendidikan, (Yogyakarta: Arruz Media, 2012)

Roem Topatimasang, Toto Rahardjo, dan Mansour Fakih, Pendidikan Populer Membangun Kesadaran (Yogyakarta, Kritis, PRESS, 2010)

Smith, William A., Conscientizacou Tujuan Pendidikan Paulo Freire, Pen. Agung Prihantoro,
(Yogyakarta: Pustaka Pelajar,2001)

Sardy, Martin, Mencari Identitas Pendidikan. (Bandung: Alumni, 1981)

Tim Penyusun Kamus Pusat Pembinaan dan Pengembangan Bahasa Departemen Pendidikan dan Kebudayaan, Kamus Besar Bahasa Indonesia, (Jakarta: Balai Pustaka, 1991)

Yamin, Moh., Menggugat Pendidikan Indonesia Belajar dari Paulo Freire dan Ki Hajar Dewantara, (Jogjakarta: Arr - Ruzz Media,2009) 